\title{
OPTIMIZING STRENGTH OF PLASTIC COMPONENT OF SAW DUST
}

\section{WASTE}

\author{
Shashi Prakash Verma ${ }^{1}$, Ashutosh Singh ${ }^{2}$, Kamlesh Singh ${ }^{3}$ \\ ${ }^{1} M$ Tech Student, (CAD/CAM), Ambalika Institute of Management \& Technology, Lucknow (India) \\ ${ }^{2}$ M Tech Student, (CAD/CAM), Ambalika Institute of Management \& Technology, Lucknow (India) \\ ${ }^{3}$ Department of Mechanical Engineering, Ambalika Institute of Management \& Technology, Lucknow (India)
}

\begin{abstract}
This paper presents the optimisation of strength of a plastic components of sawdust waste. Plastic components are organic materials which are sustainable and show potential for the manufacturing of components which are eco-friendly. The motive of this study is to research the minimum variance and optimum properties that can be obtained while manufacturing the product. This segment mostly Particles of saw dust waste is taken as a front noise factor. The result will be based on the Taguchi method in the optimizing strength of plastic component of saw dust waste.
\end{abstract}

The Taguchi method has been widely used to solve problem related to design factor. Signal to noise ratio will be used to optimize the strength for plastic component manufacturing with saw dust.

Keywords: Plastic, polystyrene, strength, manufacturing, products. $* * *$

\section{INTRODUCTION}

Natural gas oils and plants help as in deriving of plastic polymers. Polymers such as polyethylene, polypropylene, etc. are extracted from ethane, ethylene, propylene, etc. from $0 \%$ to $50 \%$ of polymers are used in the preparation of various products, hence organic as well as inorganic compounds are blended to manufacture the plastic.

Plastic is a material that is available in huge range of synthetic or semi synthetic organic that can be easily used in moulding procedure to manufacture different products of complex and typical shape and size. It can be easily deformed without any breaking but at a particular temperature. Due to its certain properties like 1. Low cost

2. Easily available

3. Ease in manufacturing

4. Water resistant

Various range of products of plastics are available from pen to spaceships. Plastics have already replaced many household products made of wood, iron, leather, glass, etc. as these products are costly and less in availability. Even now these days plumbing in the houses and buildings are done with the plastic pipes. Toys are prepared with plastics and in automobile industry too plastics are used.

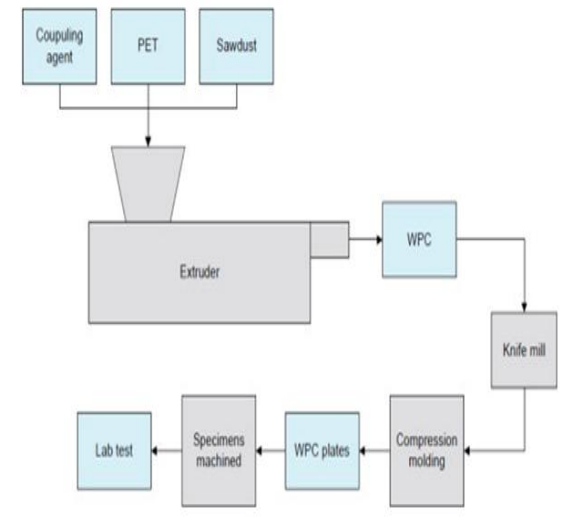

Figure 1. Description of the manufacturing process of the specimens

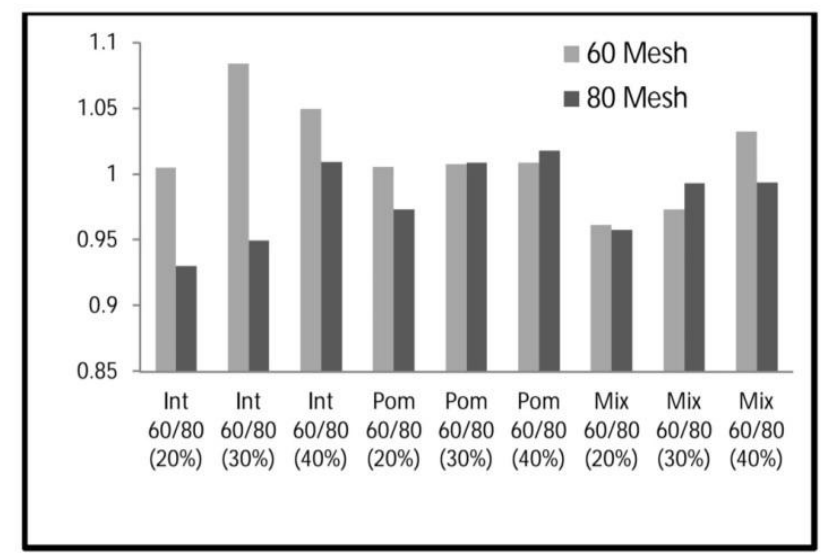

Fig. 2. Averages number of particle density size of 60 and 80 mesh 


\section{PROCESS}

Sawdust of plastics is recycled and the reprocessed to manufacture new products, recycling of plastics is a effort made to reduce plastic pollution in global as tonnes of plastic waste enters the ocean every year. Hence saw dust of plastic is used for manufacturing various plastic composites but before manufacturing any product of plastics the most important thing is to short out the various plastic scrap so that the minimum variance and optimum properties can be achieved from the particular product sorting of plastics can be done manually or with the help of various techniques such as magnetic separation, air separation, filtration, etc.



Fig. 3. Flow of manufacturing and testing processes of plastic

\subsection{Taguchi Technique}

Dr. Genichi developed Taguchi technique he developed the basic of robust design and implemented his basic idea in manufacturing different products. Quality of the can be optimised by using Taguchi technique in the product. By implementing basic engineering the cost of product can be reduced and various properties like strength density can be increased other factors like manufacturing, workmanship, material shows different variations process in construction is known as robust design. Static and dynamic changes are two classified categories of system in engineering



In experimental design various factors like clamping force, volume, suppliers, accuracy, hardness, material, speed ,temperature, time, pressure, takes effects in the manufacturing of plastic product

\section{EXPERIMENTAL DESIGN}

Experimental design procedure can be done in four steps:1. Screening- variables affecting the quality of product should be identified and should be reduced.

2. Optimisation:- optimal values should be identified from experimental factors.

3. Planning:- planning of the experiment and defining the problems and its objectives.

4. Verification:- result should be evaluated after performing experiment procedure so that it is more accurate in manufacturing plastic product

\section{Steps to be taken for Taguchi Experimental Design}

Taguchi experiment was used to find the optimal values and optimising the strength of plastic composite.

To important terms used is Orthogonal Arrays and Signal to Noise noise ratio. Rule of manufacturing is System design, Parameter design, Tolerence design. SN ratio ratio is given by-

$$
\mathrm{S} / \mathrm{N}=-10 \log 10(\mathrm{MSD})
$$

$\underline{\text { Larger the best }}$

$$
\mathrm{S} / \mathrm{N}=(-) 10 \log 10\left(1 / \mathrm{n} \Sigma 1 / \mathrm{y}_{\mathrm{i}}^{2}\right)
$$

$\underline{\text { Smaller the better }}$

$$
\mathrm{S} / \mathrm{N}=(-) 10 \log 10\left(1 / \mathrm{n} \Sigma \mathrm{y}_{\mathrm{i}}^{2}\right)
$$

Nominal the best

$$
\mathrm{S} / \mathrm{N}=(-) 10 \log _{10}\left[\mu^{2} / \sigma^{2}\right]
$$

\section{EXPERIMENTATION}

Product of plastic saw waste manufactured by a machine is experimented under various factors and conditions during production. Product to be focused under the study should be made of plastic saw dust waste. Further with the help of experimental design several factors are calculated and then documented.

Taguchi optimization then will be be used to best evaluate and optimise the plastic product made up of sawdust waste. Considering several factors like temperature, pressure, speed, time.

Material taken for experiment is Low Density Polyethylene 16MA-400. Properties of LDPE are mentioned in table below. 16MA400 is an injection moulding grade film grade LDPE produced by high pressure. The high melt flow index makes it ideal for moulding of very thin, 


\subsection{Properties of component}

\begin{tabular}{|l|l|l|}
\hline Property & Typical Value & Unit \\
\hline Density $\left(23^{\circ} \mathrm{C}\right)$ & $0.915-1.13 \mathrm{~g} / \mathrm{cc}$ & $\mathrm{g} / \mathrm{cm}^{3}$ \\
\hline Base resin melt index & $0.330-7.00$ & $\mathrm{~g} / 10 \mathrm{~min}$ \\
\hline Yield Tensile strength & $9.00-17.9$ & $\mathrm{MPa}$ \\
\hline Yield Elongation & 40 & $\%$ \\
\hline Modulus & 140 & $\mathrm{MPa}$ \\
\hline
\end{tabular}

Three levels of processing parameters and L9 orthogonal array are selected. The process factors and levels are mentioned in table below and L9 orthogonal array is mentioned in table below.

\begin{tabular}{|l|l|l|l|l|}
\hline Sr. No. & Factors & Level 1 & Level 2 & Level 3 \\
\hline 1 & Melting Temp. $\left({ }^{\circ} \mathrm{C}\right)$ & 185 & 195 & 205 \\
\hline 2 & $\begin{array}{l}\text { Pressure of injecting, } \\
\text { (MPa) }\end{array}$ & 50 & 55 & 65 \\
\hline 3 & $\begin{array}{l}\text { Refilling pressure, C } \\
(\mathrm{MPa})\end{array}$ & 70 & 75 & 80 \\
\hline 4 & Time to cool, $(\mathrm{s})$ & 5 & 7 & 10 \\
\hline
\end{tabular}

\subsection{Process parameters and level}

\begin{tabular}{|l|l|l|l|l|}
\hline $\begin{array}{l}\text { Sr. } \\
\text { No. }\end{array}$ & $\begin{array}{l}\text { Melting } \\
\text { temp }\end{array}$ & $\begin{array}{l}\text { Injecting } \\
\text { pressure }\end{array}$ & $\begin{array}{l}\text { Refilling } \\
\text { pressure }\end{array}$ & $\begin{array}{l}\text { Cooling } \\
\text { time }\end{array}$ \\
\hline 1 & 1 & 1 & 1 & 1 \\
\hline 2 & 1 & 2 & 2 & 2 \\
\hline 3 & 1 & 3 & 3 & 3 \\
\hline 4 & 2 & 1 & 2 & 3 \\
\hline 5 & 2 & 2 & 3 & 1 \\
\hline 6 & 2 & 3 & 1 & 2 \\
\hline 7 & 3 & 1 & 3 & 2 \\
\hline 8 & 3 & 2 & 1 & 3 \\
\hline 9 & 3 & 3 & 2 & 1 \\
\hline
\end{tabular}

\subsection{0rthogonal array}

\subsubsection{Shrinkage Measurement}

$$
\mathrm{S}=\left(\mathrm{D}_{\mathrm{m}}-\mathrm{D}_{\mathrm{p}}\right) / \mathrm{D}_{\mathrm{m}} \mathrm{X} 100
$$

Here, $D_{m}$ is mould dimension, $D_{p}$ is part dimension and $S$ is the shrinkage

In this study lower value of shrinkage behaviour is expected to be obtained. Thus, $\mathrm{S} / \mathrm{N}$ ratio is better for the loer the best and now this is applied in the analysis of experimental result, which is given below in table.

\begin{tabular}{|l|l|l|l|l|}
\hline Melting & $\begin{array}{l}\text { Injection } \\
\text { pressure, }\end{array}$ & $\begin{array}{l}\text { Refilling } \\
\text { pressure, }\end{array}$ & Cooling & Shrinkage \\
\hline $185^{\circ} \mathrm{C}$ & $50 \mathrm{MPa}$ & $70 \mathrm{MPa}$ & $5^{\circ} \mathrm{C}$ & $1.437 \%$ \\
\hline $185^{\circ} \mathrm{C}$ & $55 \mathrm{MPa}$ & $75 \mathrm{MPa}$ & $6^{\circ} \mathrm{C}$ & $1.48 \%$ \\
\hline $185^{\circ} \mathrm{C}$ & $65 \mathrm{MPa}$ & $80 \mathrm{MPa}$ & $10^{\circ} \mathrm{C}$ & $1.32 \%$ \\
\hline $195^{\circ} \mathrm{C}$ & $50 \mathrm{MPa}$ & $75 \mathrm{MPa}$ & $9^{\circ} \mathrm{C}$ & $1.327 \%$ \\
\hline $195^{\circ} \mathrm{C}$ & $55 \mathrm{MPa}$ & $80 \mathrm{MPa}$ & $5^{\circ} \mathrm{C}$ & $1 \%$ \\
\hline $195^{\circ} \mathrm{C}$ & $65 \mathrm{MPa}$ & $70 \mathrm{MPa}$ & $8^{\circ} \mathrm{C}$ & $1.50 \%$ \\
\hline $205^{\circ} \mathrm{C}$ & $50 \mathrm{MPa}$ & $80 \mathrm{MPa}$ & $7^{\circ} \mathrm{C}$ & $1.224 \%$ \\
\hline $205^{\circ} \mathrm{C}$ & $55 \mathrm{MPa}$ & $70 \mathrm{MPa}$ & $9^{\circ} \mathrm{C}$ & $1.32 \%$ \\
\hline $205^{\circ} \mathrm{C}$ & $65 \mathrm{MPa}$ & $75 \mathrm{MPa}$ & $50^{\circ} \mathrm{C}$ & $1.68 \%$ \\
\hline
\end{tabular}

\subsubsection{Response table for $\mathrm{s} / \mathrm{n}$ ratio}

\begin{tabular}{|c|c|c|c|c|}
\hline Sr. No. & $\begin{array}{l}\text { Melting } \\
\text { Temp, } \\
\text { (C) }\end{array}$ & $\begin{array}{l}\text { Injection } \\
\text { pressure, } \\
\text { B (MPa) }\end{array}$ & \begin{tabular}{|l|} 
Refill \\
ing \\
press \\
ure, \\
C \\
(MPa \\
\end{tabular} & $\begin{array}{l}\text { Cooling } \\
\text { time, D } \\
\text { (s) }\end{array}$ \\
\hline Level 1 & -3.325 & -3.198 & 3.527 & -4.256 \\
\hline Level 2 & -3.579 & -3.232 & 3.729 & -3.489 \\
\hline Level 3 & -3.788 & -3.687 & 2.785 & -2.587 \\
\hline Delta & 0.482 & 0.424 & 1.151 & 1.489 \\
\hline Rank & $\beta$ & 4 & 2 & 1 \\
\hline
\end{tabular}

The response table of the $\mathrm{S} / \mathrm{N}$ ratio is the best set of combination parameter by which determination of selecting the level with highest value for each factor. The optimal process parameter combination for Low Density Polyethylene is A, B, C, D.

The Delta value given in the table,denotes as to which factor is the most important for shrinkage of Low Density Polyethylene moulding.Cool time was found to be most effective factor for Low Density Polyethylene followed by refilling pressure.

Graph representing the above conclusion

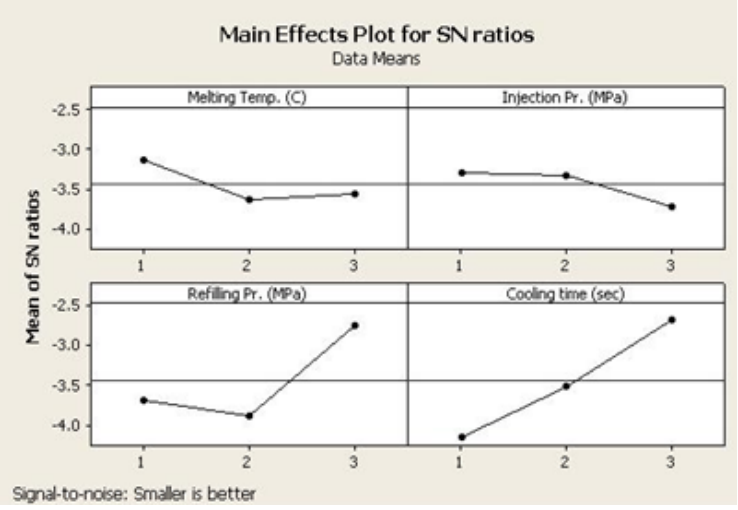




\section{CONCLUSION}

The study was for finding out the optimum level for the procedure of manufacturing plastic product from saw dust waste under Taguchi technique. Hence after performing Taguchi technique we achieve several parameters like minimum compression and maximum bending and testing of the plastic product. By applying Taguchi techniques as well as other manufacturing procedure we observe that maximum reduction in the bending and twisting of plastic component.

\section{REFERENCES}

[1] J.A. Brydson, "Plastic materials", ButterworthHeinmann: Oxford,1995.

[2] Taguchi G, Introduction to quality engineering in plasic. New York; Mc Graw Hill;1990

[3] D. Kusi, T. Kek, J. M. Slabe, R. Svecko, and J. Grum, "The impact of process parameters of plastic composite manufaturing," Polymer Testing, vol. 32, pp. 583-593, May 2013

[4] Narsimha M, Rejakumar R. Plastic pipe defects minimization. International Journal of Innovative R \& D 2013; 2(5):1337-1351.

[5] Lebal N, Puissant S, Schmidt F. Application of extrusion process Journal of Material Forming 2010; 3(1):47-58.

[6] Chen, W.C., Fu, G.L., Tai, P.H. and Deng, W.J. (2009).Optimizing of plastic for MIMO plastic. Expert Systems with Applications, 36, 1114-1122. 